\title{
Optimizing social-ecological analysis of coupled human- river systems through the integration of conceptual frameworks: the case of the Savegre watershed, Costa Rica
}

\section{Optimizando el análisis socio-ecológico de sistemas acoplados humano-fluviales a través de la integración de marcos conceptuales: el caso de la cuenca del Savegre, Costa Rica}

\author{
Edgar Espinoza-Cisneros ${ }^{1}$ \\ School of Geography, University of Costa Rica \\ Indiana University-Bloomington, U.S.A.
}

\begin{abstract}
Social-ecological systems, given their immanent complexity and unpredictability, pose intricate management challenges. Conceptual/analytical frameworks that more holistically integrate coupled social and natural systems and their basic interdependencies and interactions can significantly improve management and research efforts at multiple levels, specifically by accounting for the complex, multi-scalar processes involved, including the dynamics of distal and more proximate causal factors, as well as how they manifest and evolve in space and time. This paper presents a synthesis from a social-ecological analysis of the Savegre river watershed in Costa Rica, a recently designated UNESCO Biosphere Reserve. Through this exercise, the watershed is conceptualized as a coupled social-ecological system, with complex interconnections among social, ecological and physical components, for developing research agendas or specific normative efforts. Syntheses like the one presented here are particularly useful for more in-depth explorations of social-ecological issues, especially collective action problems derived from human-environment interactions at
\end{abstract}

1 Doctorando en Geografía por la Universidad de Indiana, E.E.U.U. Investigador asociado del Centro de Análisis de Paisajes Socio-Ecológicos de la Universidad de Indiana, E.E.U.U. Profesor Instructor en la Escuela de Geografía, Universidad de Costa Rica (UCR), San Pedro de Montes de Oca, Costa Rica. Correo-e: edgar.espinoza@ucr.ac.cr

Este artículo corresponde a la ponencia presentada en el 35th Conference of Latin American Geographers realizada en San José, Costa Rica del 20 al 22 de mayo del 2018. 
Edgar Espinoza-Cisneros. Optimizando el análisis socio-ecológico de sistemas acoplados humano-fluviales a través de la integración de marcos conceptuales: el caso de la cuenca del Savegre, Costa Rica

various scales. More effective formal and informal normative solutions to pressing sustainability dilemmas can also be envisioned through similar exercises.

Keywords: social-ecological analysis, watershed, conceptual framework, Savegre, sustainability.

\begin{abstract}
Resumen
Los sistemas socio-ecológicos, dada su inmanente complejidad e impredecibilidad, llevan a intrincados retos de manejo. Marcos conceptuales/analíticos que integran de manera más holística los sistemas sociales y naturales así como sus interdependencias e interacciones básicas pueden de manera significativa mejorar los esfuerzos de manejo e investigación a múltiples niveles, específicamente al considerar los procesos complejos y multi-escalares involucrados, incluyendo las dinámicas de factores causales distales y más próximos, así como la manera en que se manifiestan y evolucionan en el espacio y tiempo. Este artículo presenta una síntesis de un análisis socio-ecológico de la cuenca del río Savegre en Costa Rica, recientemente designada como una Reserva de la Biósfera de la UNESCO. A través de este ejercicio, la cuenca es conceptualizada como un sistema socio-ecológico acoplado, con interconexiones complejas entre componentes sociales, ecológicos y físicos, para el desarrollo de agendas de investigación o esfuerzos normativos específicos. Síntesis como la que aquí se presenta son particularmente útiles para exploraciones más profundas de problemáticas socio-ecológicas, especialmente problemas de acción colectiva derivados de interacciones ser humano-medio ambiente a varias escalas. Soluciones normativas formales e informales más efectivas a dilemas de sostenibilidad acuciantes también se pueden concebir a través de ejercicios similares.
\end{abstract}

Palabras clave: análisis socio-ecológico, cuenca, marco conceptual, Savegre, sostenibilidad.

\title{
Introduction
}

Environmental management has traditionally lacked integrative approaches that better capture how social and biophysical components interact to derive particular outcomes (Liu et al., 2015). Commonly, social science disciplines have overlooked the physical-ecological and vice-versa (Galaz et al., 2008; Ives \& Kendal, 2014). While recently there has been a growing tendency to consider both components conjointly in research and assessments (Collins et al., 2011; Young et al., 2006), many still fail to clearly indicate how the multiple components involved interact in space and time and at multiple scales (Galaz et al., 2008; Liu et al., 2007). This imperative need to better account for complexity in human-environment interactions has led to the design of multi-disciplinary conceptual frameworks that outline the fundamental components of human-environment interactions and their general relationships (Anderies et al., 2004; Binder et al., 2013; Liu et al., 2013; Vörösmarty et al., 2010). These frameworks are particularly useful as they provide a meta-theoretical language that reconciles multiple 
Edgar Espinoza-Cisneros. Optimizing social-ecological analysis of coupled human-river systems through the integration of conceptual frameworks: the case of the Savegre watershed, Costa Rica

theoretical stances ${ }^{2}$, and allow for comparative analyses and buildup of empirically-based knowledge. One renowned framework for the analysis of social-ecological systems (SES) is the Social-Ecological Systems framework (Ostrom, 2007, 2009). The SESF identifies key subsystems involved in human-environment interactions, as well as their subcomponents or variables within a multi-tier scheme. The SESF has been widely utilized in the context of collective action problems involving common-pool natural resources, but has evolved through methodological enhancements (Frey \& Rusch, 2013; Hinkel et al., 2014; Leslie et al., 2015; Schlüter et al. 2014), or applications to particular social-ecological systems and analytical scales (Brondizio et al., 2016b; Delgado-Serrano \& Ramos, 2015).

Despite the comprehensiveness of the SESF, however, it has been critiqued for its tenuous representation of interconnections between system components (Hinkel et al., 2015). Also, cases that have conceptualized watersheds as complex SES have surprisingly been few (Cabello et al., 2015), despite the ubiquitous use of the watershed concept as a spatial unit integrating social and hydrological processes (Molle, 2009). In this paper, a watershed system recently designated a UNESCO Biosphere Reserve for its ecological and socio-economic importance, is characterized as an SES drawing from two conceptual frameworks, concretely the SESF and Brondizio et al.'s (2016b) framework for estuary and deltaic systems (henceforth SES Deltas). Coupling these frameworks can better situate a multi-tier variable scheme such as that of the SESF within the context of a functionally-interdependent social-hydrological system (SES Deltas), potentially enhancing social-ecological assessments and providing more comprehensive analytical foundations for further, more refined formulations of sustainability research questions (Binder et al., 2013; Brondizio et al., 2016b). In the context of this recent biosphere reserve designation, these exercises can be especially useful for guiding new or existing management objectives and planning efforts.

\section{Study area}

Situated in Costa Rica's Central Pacific region, the Savegre river watershed (hereafter SW) covers approximately $600 \mathrm{~km}^{2}$, or about $1.15 \%$ of the country's landmass (Figure 1). It is among the most biologically

2 For an comprehensive analysis of social-ecological frameworks, see Binder et al. (2013) 
diverse areas in the country, hosting an array of natural and semi-natural ecosystems along its steep elevation gradient (Acevedo et al., 2002; Estrada \& Zamora, 2004; Sánchez et al., 2004). The watershed's stem fluvial courses are the Savegre and División rivers, which converge approximately 12 linear km. northeast from the river's mouth. Smallholder productive systems predominate throughout the watershed (usually mixed crop-livestock), but large-scale agricultural and cattle raising units are also found, especially in the mid and lower sections. In the upper watershed, tourism and trout aquaculture are common. Main cultivated crops include coffee, oil palm, and a variety of fruits. Furthermore, about $60 \%$ of the area is under some formal level of protection, yet subject to increasing pressures in recent decades due to the expansion of the agricultural frontier, intensive aquaculture activities, destructive fishing practices, and proposals for medium-scale hydroelectric projects (CEDARENA, 2001; MINAE, 2004; Sánchez et al., 2004).

Figure 1. General map of the SW showing elevation gradient, main communities and fluvial network.

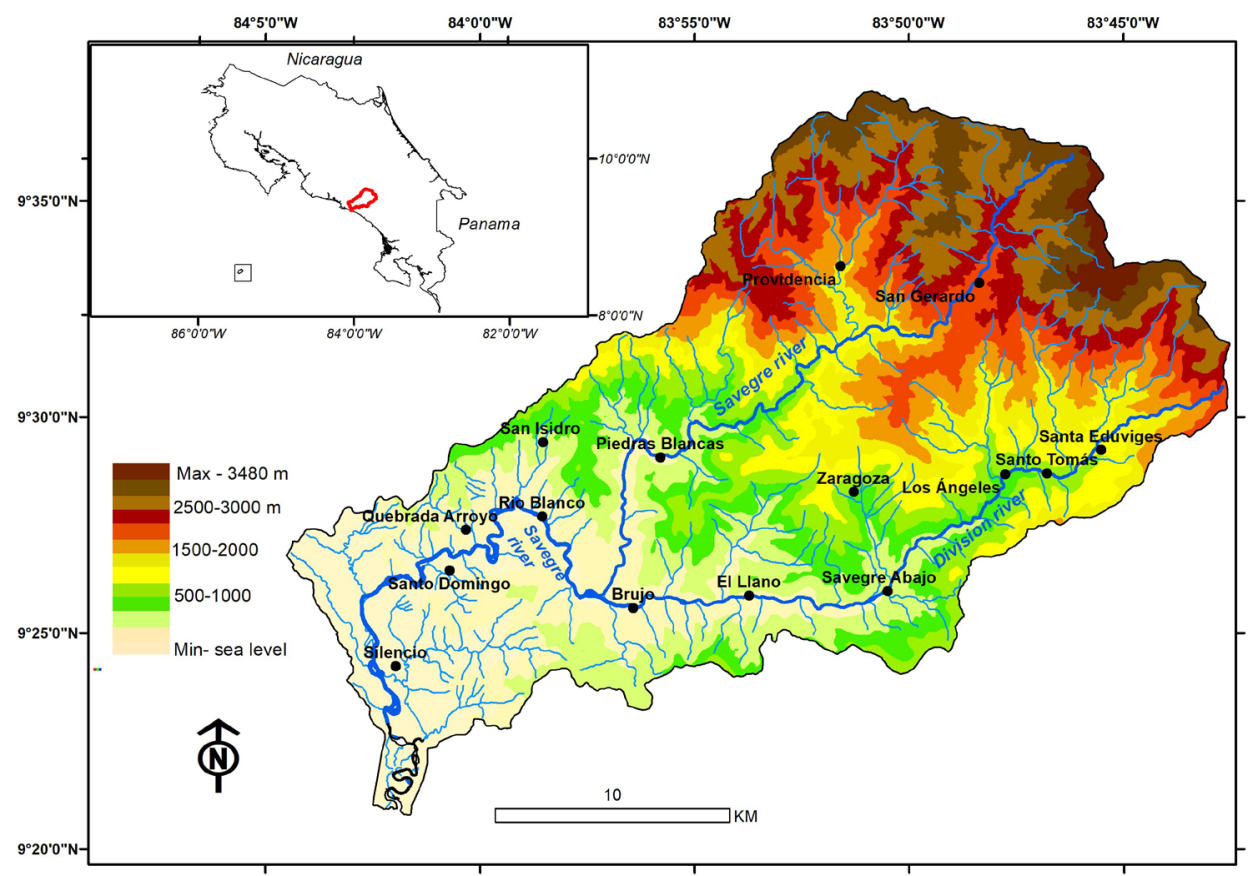


Edgar Espinoza-Cisneros. Optimizing social-ecological analysis of coupled human-river systems through the integration of conceptual frameworks: the case of the Savegre watershed, Costa Rica

\section{Methods}

The SESF (Ostrom, 2009) and SES Deltas (Brondizio et al., 2016b) conceptual frameworks were utilized to analyze the SW as an SES (Figures $3 \& 4$ ). It is worth noting that these frameworks were ontologically rather than operationally integrated in this analysis. A simplified outline of how both frameworks were used here is presented in Figure 2. The focal sustainability problem and core SES are first defined, followed by a definition of the principal social-ecological telecouplings ${ }^{3}$ and interdependencies driving the problem as well as a brief assessment of the analytical boundaries of the SES. These three steps from the SES Deltas framework in particular help better contextualize the subsequent characterization using the SESF, mostly by providing a more comprehensive perspective of key interlinkages among SESF variables within the context of a highly functionally interdependent hydrological system.

Figure 2. Basic outline of conceptual framework integration used in this paper. After following the first three steps in the SES Deltas framework, a more informed application of the SESF was possible through a more explicit account of the key interrelationships between relevant system components in hydrological systems.

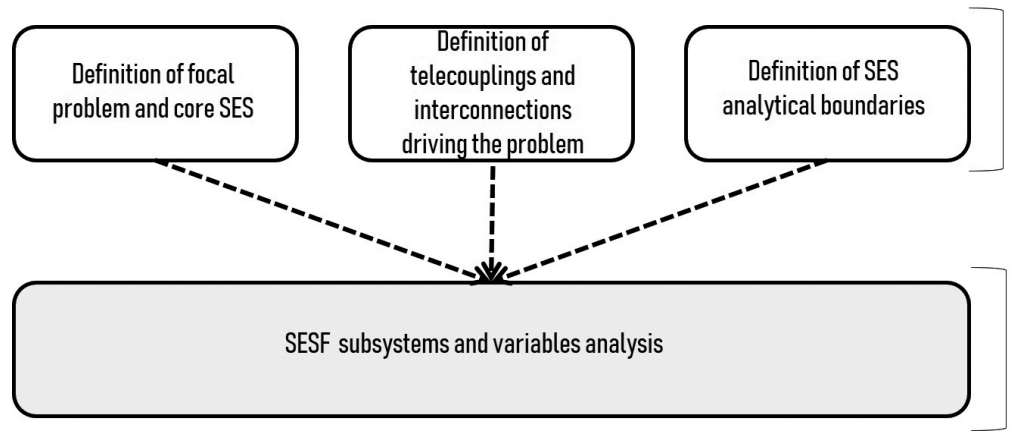

SESDeltas Framework

Social-Ecological

Systems Framework

As an initial step, the SESF's structure was reviewed with key informants and other relevant actors to identify and narrow down the main components and variables potentially influencing human-river interactions in the SW. Each SESF second and third level variable was reviewed,

3 The definition of telecoupling used in Brondizio et al. (2016b) is also used here. It refers "both to the interconnection between social and natural systems and to the distant causes of local phenomena". 
Edgar Espinoza-Cisneros. Optimizando el análisis socio-ecológico de sistemas acoplados humano-fluviales a través de la integración de marcos conceptuales: el caso de la cuenca del Savegre, Costa Rica

collected and further discussed with the participants in terms of its potential contribution to understanding human-river interactions within the SW, using the descriptions outlined in Delgado-Serrano and Ramos (2015) as a guide. Variable selection was also informed by previous studies using the SESF for water resource SES (e.g. Nagendra \& Ostrom, 2014).

Figure 3. Social-Ecological Systems Framework diagram, with main components and interactions. From McGinnis \& Ostrom, (2014).

Social, Economic, and Political Settings(S)

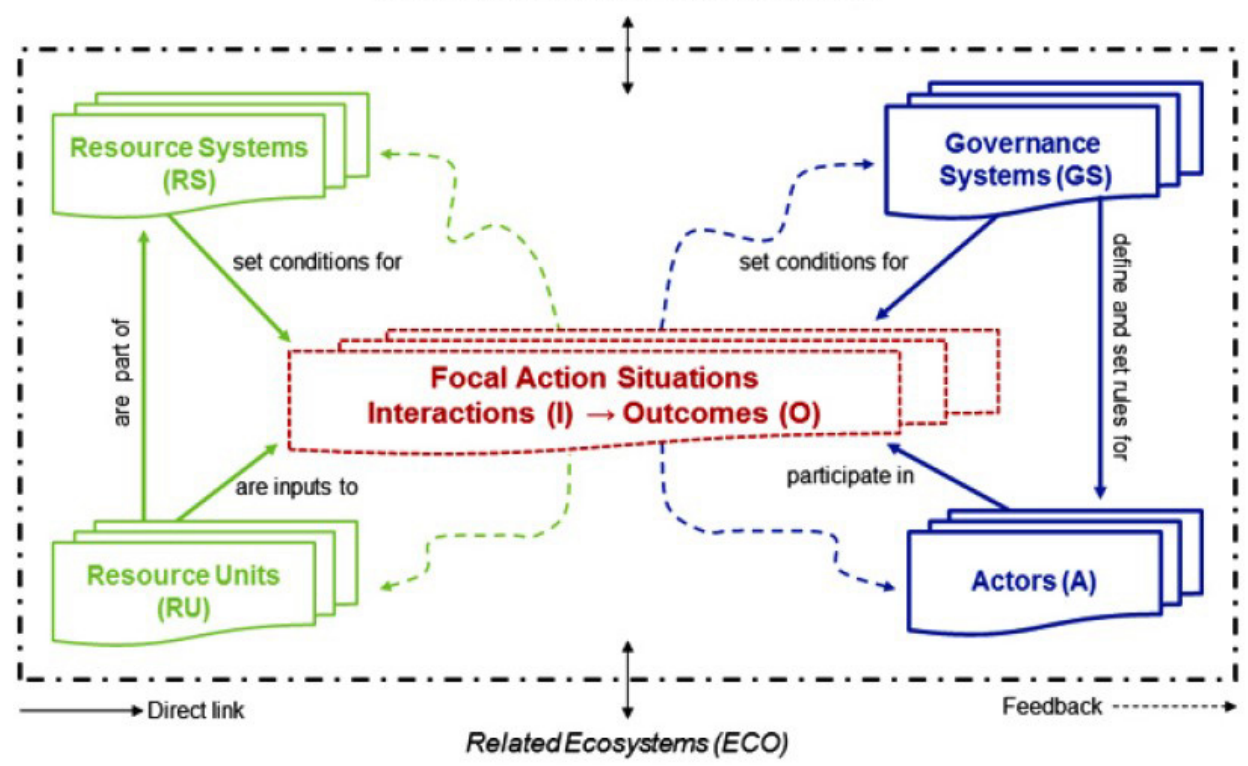


Edgar Espinoza-Cisneros. Optimizing social-ecological analysis of coupled human-river systems through the integration of conceptual frameworks: the case of the Savegre watershed, Costa Rica

Figure 4. Conceptual framework by Brondizio et al., (2016a,b) applied to deltaic regions, which allows a characterization and analysis of deltas as coupled social-ecological systems (SES). Figure taken from Brondizio et al., (2016a)

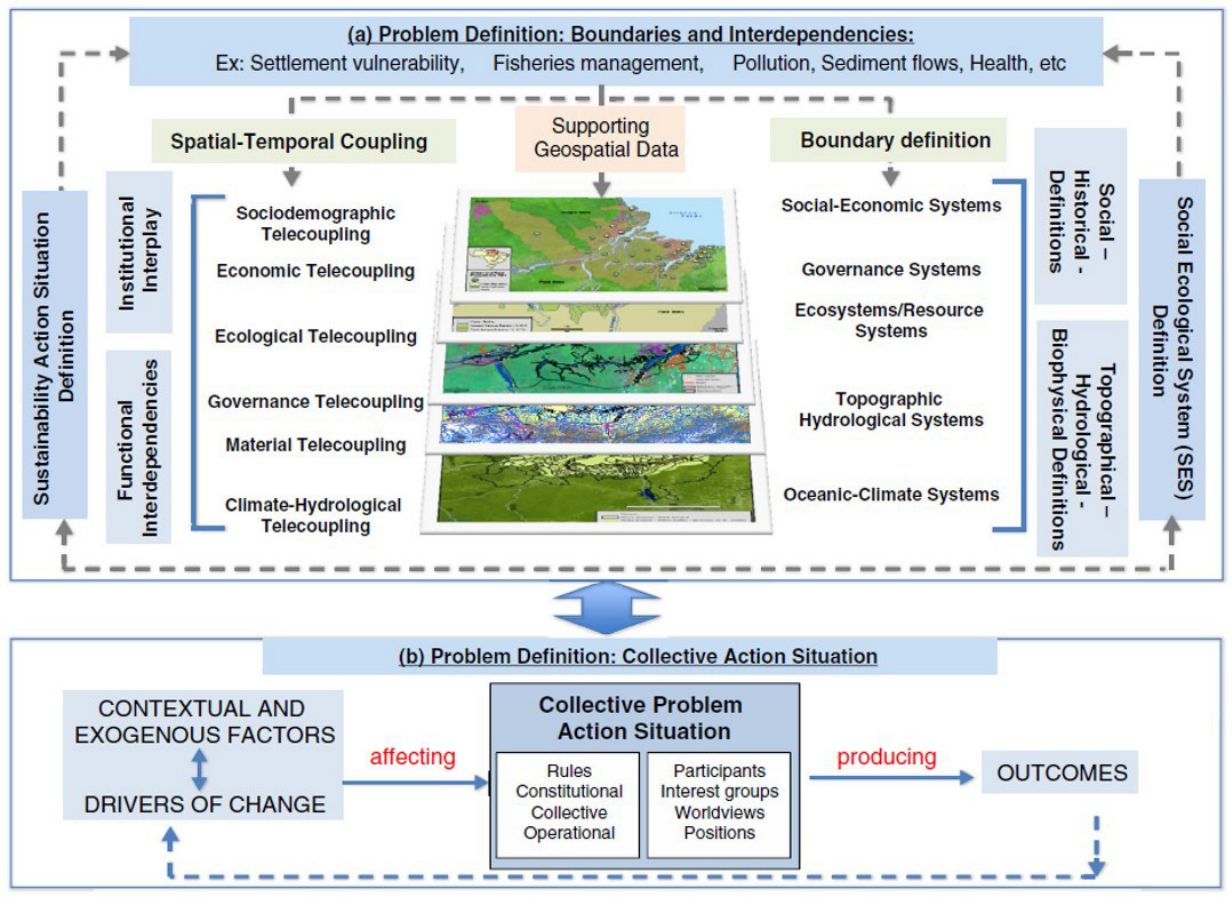

Once key framework variables were identified, they were examined in detail in the context of the SW. For this, peer-reviewed and grey literature was reviewed and data were gathered from available social, environmental and geospatial databases ${ }^{4}$, complemented with explicit reports (interviews and focus groups) and systematic field observations conducted during intermittent site visits over a 10 month period (December 2016September 2017). Interviewees and focus group participants included community development association members, tourism entrepreneurs, agricultural extension officers, rural aqueduct managers, public institution representatives, landholders and researchers. Interviews and discussions

4 These data included political-administrative divisions, protected areas, road networks, land use, precipitation, temperature, watershed drainage patterns, topography and relief, soil types, among other, and were used for visual and analytical overlays as part of the analysis with participants. 
were also guided by variable descriptions provided in Delgado-Serrano and Ramos (2015), and followed a "systems-type" approach to capture the perceived connections between proximate causes and distal drivers involved in the watershed dynamics, feedback mechanisms at play, and a general characterization of these interactions.

\section{Results}

\section{Definition of focal problem in the $\mathrm{SW}$ social-ecological system}

In the SW, fluvial system and its associated provision of ecosystem services (Table 1) has been facing increasing pressures over the last two decades due to the expansion of the agricultural and cattle frontiers in some regions of the watershed, intensive agrochemical use in steep topography, unregulated aquaculture farming, and destructive fishing practices (MINAE, 2004; SINAC, 2017). Before 2015, initiatives of hydroelectric projects had also been proposed, but through a government decree they were banned for a 25 year period (2015-2040) (Gobierno de Costa Rica, 2015).

Table 1. Main ecosystem services provided by the watershed system and their proximate and underlying drivers of change, determined from fieldwork and actor consultation.

\begin{tabular}{|c|c|c|c|}
\hline $\begin{array}{l}\text { Watershed } \\
\text { section }\end{array}$ & Main ecosystem services provided* & $\begin{array}{l}\text { Proximate drivers of } \\
\text { ecosystem service change }\end{array}$ & $\begin{array}{l}\text { Underlying drivers of } \\
\text { ecosystem service change }\end{array}$ \\
\hline Upper & $\begin{array}{l}\mathrm{P} \text {-- Food production (fruits, } \\
\text { livestock, trout aquaculture), fresh } \\
\text { water, bioprospecting. } \\
\mathrm{R} \text { - Natural hazard regulation, water } \\
\text { and erosion regulation, water } \\
\text { purification, pollination. } \\
\mathrm{C} \text { - Recreation and tourism, aesthetic } \\
\text { appreciation, sense of place, cultural } \\
\text { heritage values, social relations. }\end{array}$ & $\begin{array}{l}\text { Intensive aquaculture farms, } \\
\text { unplanned tourism activities, } \\
\text { agricultural expansion. }\end{array}$ & $\begin{array}{l}\text { Climate change, global } \\
\text { tourism and crop } \\
\text { commodity markets, } \\
\text { economic structures. }\end{array}$ \\
\hline Middle & $\begin{array}{l}\mathrm{P} \text {-- Food production (coffee, } \\
\text { livestock), fresh water. } \\
\mathrm{R} \text {-- Natural hazard regulation, water } \\
\text { and erosion regulation services. } \\
\mathrm{C} \text {-- Cultural heritage values, social } \\
\text { relations. }\end{array}$ & $\begin{array}{l}\text { Agricultural expansion, } \\
\text { hydroelectric projects (in the } \\
\text { future), biophysical trigger } \\
\text { events (e.g. more frequent } \\
\text { and intense mass } \\
\text { movements). }\end{array}$ & $\begin{array}{l}\text { Global crop commodity } \\
\text { markets, economic } \\
\text { structures, property rights } \\
\text { and land tenure, in- } \\
\text { migration, institutional } \\
\text { regulatory capacities. }\end{array}$ \\
\hline Lower & $\begin{array}{l}\mathrm{P} \text {-- Food production (oil palm, } \\
\text { livestock, rice), fresh water, timber. } \\
\mathrm{R} \text {-- Water regulation services, } \\
\text { pollination. } \\
\mathrm{C} \text {-- Recreation and tourism, aesthetic } \\
\text { appreciation. }\end{array}$ & $\begin{array}{l}\text { Agricultural expansion, } \\
\text { hydroelectric projects (in the } \\
\text { future) and other } \\
\text { infrastructure extension. }\end{array}$ & $\begin{array}{l}\text { Global markets, } \\
\text { institutional regulatory } \\
\text { capacity, agricultural } \\
\text { production factors, public } \\
\text { attitudes and values, policy } \\
\text { climate. }\end{array}$ \\
\hline
\end{tabular}

*as per MEA (2005). $\mathrm{P}=$ Provisioning ecosystem services, $\mathrm{R}=$ Regulating ecosystem services, $\mathrm{C}=$ Cultural ecosystem services. 
Edgar Espinoza-Cisneros. Optimizing social-ecological analysis of coupled human-river systems through the integration of conceptual frameworks: the case of the Savegre watershed, Costa Rica

Starting in the 1970s, the SW underwent an intense period of landscape change, coinciding also with country-wide trends (Sanchez-Azofeifa, 2000; Sánchez-Azofeifa et al., 2003). Thriving meat prices internationally led to an aggressive expansion of the cattle frontier (Arroyo-Mora et al., 2005; Harvey \& Haber, 1998), and in the SW, it occurred particularly in the upper and middle sections. During the late 1980s, booming ecotourism led to a recovery of forest cover, notably in the upper watershed. However, this occurred concomitantly with a proliferation of coffee plantations in the División river sub-watershed, albeit mostly occurring over former pasturelands. Also, blast and poison fishing are not uncommon in the SW, especially in the mid to lower sections. Use of dragging nets and spearguns are also customary and are commonly denounced by locals, although enforcement by authorities of these practices is almost nonexistent.

\section{Key spatial-temporal telecouplings and analytical boundaries of SES}

Feedback mechanisms involving steep topography, intense precipitation events and land covers associated with certain land uses are principal factors influencing fluvial system health in the SW. Synergetic relationships between these components lead to intense runoff processes in the upper and mid watershed, where sheet flows transport sediments, organic matter, agrochemicals and other materials to the fluvial system.

Regarding land use, sociodemographic dynamics linked to cash crop cultivation are key to understand the SW SES. Coffee cultivation, for instance, drives regional migratory processes involving labor from Nicaragua and Panama (Figure 5). Also, domestic and international out-migration is common, influencing land use in various ways. Emigrants based in the United States, for instance, typically invest in the area by purchasing land to produce, build recreational homes, and other infrastructure. Many young members of households (17-30 years) also migrate domestically to nearby urban centers like San Isidro, Cartago and San José in search of better job and educational opportunities, further creating more dependence on foreign migrant labor for rural production activities. 
Figure 5. Nested levels of analysis with their most relevant socialecological issues and interaction dynamics influencing fluvial system health in the SW, identified after using SES Deltas framework. Bold outline indicates the focal action situation level of analysis. 'Global' and 'household/individual' images taken from Wikimedia Commons.

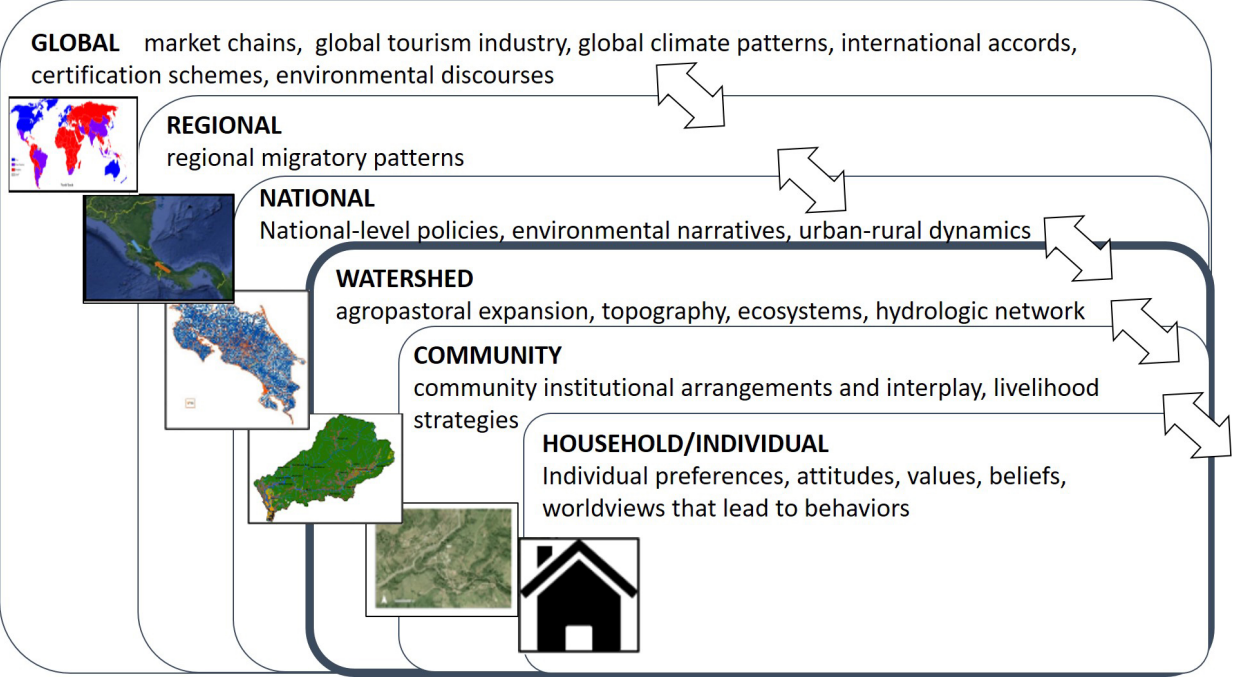

Market dynamics are also important land use drivers within the SW. Main domestic markets for livestock and most crops produced in the SW are primarily the settlement centers of San Isidro, Quepos, and Cartago. There are also diverse and consolidated international markets for most productive and service activities in the SW, predominantly in Europe and North America (USDA, 2017). In the case of large cash crops, most producers are commercially linked to larger intermediaries that collect production for processing and/or selling, or are associated with a cooperative. For coffee and oil palm, the most intensely cultivated crops in the SW, the majority of producers are organized into or otherwise associated with cooperatives that, in most cases, follow socio-environmental certification schemes that promote best management practices. These certifications are also important in the SW insofar as they provide some degree of economic stability to producers through guaranteed minimum pay rates irrespective of market price fluctuations. 
Edgar Espinoza-Cisneros. Optimizing social-ecological analysis of coupled human-river systems through the integration of conceptual frameworks: the case of the Savegre watershed, Costa Rica

Meanwhile, insecure land tenure is a concern for residents within the $\mathrm{SW}$, and has aggravated distrust in government authorities, particularly the Ministry of Environment (MINAE). In the SW, this problem is largely due to protected area regulations that hinder some residents from obtaining formal land ownership (CEDARENA, 2001). This situation also precludes land managers from applying to incentive-based mechanisms like payments for ecosystem services (PES) as well as having access to credits (Gago García, 2000).

Weak policy enforcement by government authorities also characterizes human-environment interactions in the SW, denoting feeble inter-institutional coordination and operational deficiencies. Perhaps the most salient example of this is the inability of government authorities to enforce poison and blast fishing practices, thereby facilitating regulatory transgressions. Further, the "institutional fit" problem is prevalent within the SW, as its area straddles across multiple administrative units, leading to a disarticulation between governance jurisdictions and hydrographic functional units (Brondizio et al., 2009; Folke et al., 2007; Young et al., 2008). This situation can disfavor integrated watershed management efforts, as reflected in the establishment of an industrial aquaculture operation in the upper Dota canton that concerned administrative authorities of other cantons regarding potential social and environmental impacts of these operations further downstream.

\section{Boundary definition}

The watershed had been defined here from the outset as the spatial unit of analysis, which undoubtedly offers analytical advantages such as a more discrete definition of boundaries based on hydrological dynamics. Indeed, an important contribution of the Deltas SES framework lies in its guidance regarding influences outside the bounds of a single analytical level (Figure 5). In the SW, it is clear that the SES cannot be properly understood by circumscribing exclusively to the watershed; for instance, without acknowledging the influence that nearby population centers outside the watershed limits like San Isidro, Quepos, and the greater San José metropolitan area have on socioeconomic processes and consequent physical-ecological effects. Further, climatic events originating outside the discrete limits of the SW have immediate and long-term consequences on human-environment interactions, as does the configuration of political-administrative units transcending these limits. 
Edgar Espinoza-Cisneros. Optimizando el análisis socio-ecológico de sistemas acoplados humano-fluviales a través de la integración de marcos conceptuales: el caso de la cuenca del Savegre, Costa Rica

\section{Synthesis from characterization using SESF}

With the background provided by the previous analysis, a summary of key findings using the SESF's multi-tiered structure follows, using however the SES Deltas framework telecoupling categories that were useful in SESF variable examination (Table 2). Key SESF variables are also referenced in parentheses in the summary text. The SESF is thus not applied standalone, but rather undergirded by an analytical perspective that facilitates the identification of interlinkages among components and variables in this particular SES. It is emphasized that while all SESF subsystems were initially considered in this exercise, not all were deemed relevant for understanding human-environment interactions associated to fluvial system health in the SW (see Table 2).

Table 2. SESF subsystems (first-tier variables) and second-tier variables considered relevant in the social-ecological analysis of the SW after consultation with informants and other participants, along with the associated dimensions of SES Deltas framework category types that were particularly helpful in variable analysis. Original source of complete SESF variable list: McGinnis \& Ostrom, (2014).

\begin{tabular}{|c|c|c|}
\hline $\begin{array}{l}\text { SESF first-tier } \\
\text { variable }\end{array}$ & SESF second-tier variable & $\begin{array}{l}\text { Associated SES Deltas framework } \\
\text { telecoupling dimensions }\end{array}$ \\
\hline $\begin{array}{l}\text { Social, economic, } \\
\text { and political } \\
\text { settings }(S)\end{array}$ & $\begin{array}{l}\text { S1- Economic development } \\
\text { S2- Demographic trends } \\
\text { S4- Other governance systems } \\
\text { S5- Markets }\end{array}$ & $\begin{array}{l}\text { Socio-demographic, economic, } \\
\text { governance }\end{array}$ \\
\hline $\begin{array}{l}\text { Resource systems } \\
\text { (RS) }\end{array}$ & $\begin{array}{l}\text { RS6- Equilibrium properties } \\
\text { RS7- Predictability of system dynamics }\end{array}$ & Material, climate-hydrological \\
\hline $\begin{array}{l}\text { Governance } \\
\text { systems (GS) }\end{array}$ & $\begin{array}{l}\text { GS1- Government organizations } \\
\text { GS3-Network structure } \\
\text { GS4-Property rights systems } \\
\text { GS8- Monitoring and sanctioning rules }\end{array}$ & Governance, socio-demographic \\
\hline $\begin{array}{l}\text { Resource unit } \\
\text { (RU) }\end{array}$ & $\begin{array}{l}\text { RU3-Interaction among resource units } \\
R U 4-\text { Economic value }\end{array}$ & Material, Governance, Economic \\
\hline Actors (A) & $\begin{array}{l}\text { A1- Number of relevant actors } \\
\text { A2- Socioeconomic attributes } \\
\text { A6- Norms/social capital } \\
\text { A7- Knowledge of SES/mental models } \\
\text { A8-Importance of resource }\end{array}$ & $\begin{array}{c}\text { Governance, economic, socio- } \\
\text { demographic }\end{array}$ \\
\hline
\end{tabular}

Economic, socio-demographic, and governance telecouplings

Broader-level processes are crucial for understanding human-environment dynamics in certain SES (e.g. (Torres Guevara et al., 2016). 
Edgar Espinoza-Cisneros. Optimizing social-ecological analysis of coupled human-river systems through the integration of conceptual frameworks: the case of the Savegre watershed, Costa Rica

Within the SW, it is clear that agents respond to structural stimuli such as market dynamics (S5), government policies (S4), technologies available, as well as demographic factors (S2). The economic situation (S1, A2) within the SW is characterized by relatively low wages, fair to poor living conditions, and scarce job and education opportunities which drive socio-demographic processes transcending watershed limits (MINAE, 2004; MINAE-AECI, 2001). Some exceptions occur at the upper section of the watershed, where tourism is firmly consolidated (Cruz Conejo, Chacón Ureña, \& Chacón Zúñiga, 2012). In agricultural activities in particular, a concern is the out-migration of young population groups (17-30) increasingly disinterested in working the land, creating greater economic uncertainty in the area. Further, the SW is characterized by low population densities, in part due to adverse topographical conditions as well as large tracts of protected areas that likewise pose limitations for settlement.

Non-monetary social values (R4) associated to community ties, individual and collective environmental identities, place attachment, and family bonding through recreational activities stand out in the SW SES. Traditions and community values towards the environment in general and riverscapes in particular were found to be germane in human-river interactions. Family histories, common settlement backgrounds and inter-generational upbringings in these riverine landscapes seem to strengthen place attachment. Residents overall express high concern for environmental problems affecting the watershed (A6), and despite the relatively low dependence on material river resources (A1, A8), they place a high non-consumptive, socio-cultural value on the river system, particularly in the mid and upper sections of the watershed.

Conflicts over river issues among actors are rare, although in areas more dependent on river resources there is greater conflict propensity; for example, intra-community skirmishes in the upper watershed involving trout farms and tourism, as well as ideological clashes related to the hydroelectric project initiatives in the middle and lower watershed where tourism is prevalent. Moreover, government organizations (GS1) with leverage in this SES include the Ministry of Environment and Energy (MINAE), Ministry of Agriculture and Cattle (MAG), and municipal authorities. As mentioned before, relations between communities and these government entities, especially MINAE, are frail, due largely to the land ownership 
problem (GS4) as well as negative perceptions toward these entities. Relatedly, deficient governmental institutional capacities in environmental matters has been something reiteratively criticized in Costa Rican policy analyses (Programa Estado de la Nación, 2016), and this arguably carries important implications for human-environment interactions in the SW particularly in how it might influence environmental stewardship and consequent actions impacting socio-ecological outcomes (GS8). Specifically, lax enforcement of policies and regulations, unclear definition of roles and responsibilities, as well as a general distrust of government entities characterize environmental governance in the SW (GS3).

\section{Material and climate-hydrological telecouplings}

One key factor in social-ecological dynamics in the SW are land uses requiring land clearing that have progressively adapted to the steep topography, favoring greater slope instability (mass movements), runoff processes, and the associated increased stream sedimentation and pollution (RS6, RS7). Upstream, the river is utilized for small scale industrial trout farming, affecting water quality for activities downstream, more specifically tourism and subsistence fishing (RU3). Furthermore, land managers overall have good knowledge of watershed hydrological dynamics (A7), including a clear conceptualization of basic watershed functional dynamics and the impacts that certain land use activities and extreme events have on aquatic and terrestrial systems within.

\section{Discussion and conclusion}

Frameworks are key to more effectively diagnose and propose solutions to human-environment problems (Vörösmarty et al., 2010). They are also useful in guiding more profound inquiry processes in research (McGinnis \& Ostrom, 2014). In this paper, two conceptual frameworks were used to improve characterization and analysis of a coupled human and natural system, to better inform normative and research efforts. Particular strengths of each conceptual framework in the context of the SES under analysis were utilized, without sacrificing their overall structure. On one hand, the SES Deltas framework helped better account for interconnections associated with complex commons such as watersheds, usually involving multiple uses and benefits (Duraiappah et al., 2014; Hinkel et al. 
Edgar Espinoza-Cisneros. Optimizing social-ecological analysis of coupled human-river systems through the integration of conceptual frameworks: the case of the Savegre watershed, Costa Rica

2015). On the other hand, the SESF provided a comprehensive roadmap of key social-ecological components and variables involved in resource governance in particular, reducing the likelihood of missing potentially relevant aspects in the analysis.

In general, this analytical integration helped uncover some of the myriad factors interacting in complex ways in space and time that condition fluvial system health and the associated provision of ecosystem services. Particularly noteworthy is the fragile relationship between land managers and government entities (e.g. MINAE) due to the insecure land tenure situation as well as the lack of autonomy at the community level to collectively address environmental problems associated to the river system, as these two factors in particular seem to preclude collective action. However, the question of whether granting formal ownership to these land managers will improve fluvial system health is indeed an important one and whose answer is elusive.

This social-ecological synthesis also accentuated the importance of considering cognitive factors in human-environment frameworks. In the SW, certain environmental beliefs, attitudes, knowledge and social values related to the fluvial system stood out as potentially important in understanding socio-ecological outcomes. SES research in general should more explicitly incorporate this socio-cultural dimension of actors, a need that has been increasingly brought up by scholars recently (Jones, Shaw, Ross, Witt, \& Pinner, 2016; Partelow \& Winkler, 2016).

Finally, integrative SES analyses like the one presented here can be exceptionally useful as foundations for research design, including the (re)formulation of research questions, objectives, and methodological approaches. Further, these more holistic frameworks are pivotal for normative purposes, to inform public policies and regulatory schemes that need to inexorably account for the complex interplay between biophysical and social systems in order to effectively achieve sustainable outcomes.

\section{Acknowledgements}

I wish to acknowledge financial support from the University of Costa Rica's (UCR) Vice-rectory of Research, under research project B6-355. I also wish to thank the following individuals at the UCR for their invaluable support in the development of this research: Isabel Avendaño-Flores, 
Edgar Espinoza-Cisneros. Optimizando el análisis socio-ecológico de sistemas acoplados humano-fluviales a través de la integración de marcos conceptuales: el caso de la cuenca del Savegre, Costa Rica

Sara Blanco-Ramírez and Jeffry Garro-Fallas. Finally, I would like to thank Eduardo Brondizio at Indiana University for his conceptual and methodological insights.

\section{References}

Acevedo, H., Bustamante, J., Paniagua, L., \& Chaves, R. (2002). Ecosistemas de la Cuenca Hidrográfica Del Río Savegre, Costa Rica. Santo Domingo de Heredia: Editorial INBio.

Anderies, J., Janssen, M., \& Ostrom, E. (2004). A framework to analyze the robustness of social-ecological systems from an institutional perspective. Ecology and society, 9(1).

Arroyo-Mora, J. P., Sánchez-Azofeifa, G. A., Rivard, B., Calvo, J. C., \& Janzen, D. H. (2005). Dynamics in landscape structure and composition for the Chorotega region, Costa Rica from 1960 to 2000. Agriculture, Ecosystems \& Environment, 106(1), 27-39.

Binder, C., Hinkel, J., Bots, P., \& Pahl-Wostl, C. (2013). Comparison of frameworks for analyzing social-ecological systems. Ecology and Society, 18(4).

Brondizio, E. S., Foufoula-Georgiou, E., Szabo, S., Vogt, N., Sebesvari, Z., Renaud, F. G., ... others. (2016a). Catalyzing action towards the sustainability of deltas. Current Opinion in Environmental Sustainability, 19, 182-194.

Brondizio, E. S., Ostrom, E., \& Young, O. R. (2009). Connectivity and the governance of multilevel social-ecological systems: The role of social capital. Annual review of environment and resources, 34, 253-278.

Brondizio, E. S., Vogt, N. D., Mansur, A. V., Anthony, E. J., Costa, S., \& Hetrick, S. (2016b). A conceptual framework for analyzing deltas as coupled social-ecological systems: an example from the Amazon River Delta. Sustainability Science, 1-19.

Cabello, V., del Moral Ituarte, L., Willaarts, B. A., \& Aguilar, M. (2015). River basins as social-ecological systems: Linking levels of societal and ecosystem water metabolism in a semiarid watershed. Ecology and Society, 20(3).

CEDARENA (Centro de Derecho Ambiental y de los Recursos Naturales). (2001). Estudio de tenencia de la tierra cuenca hidrográfica del río 
Edgar Espinoza-Cisneros. Optimizing social-ecological analysis of coupled human-river systems through the integration of conceptual frameworks: the case of the Savegre watershed, Costa Rica

Savegre y la Reserva Forestal Los Santos (p. 114). Costa Rica -Proyecto Araucaria.

Collins, S. L., Carpenter, S. R., Swinton, S. M., Orenstein, D. E., Childers, D. L., Gragson, T. L., ... others. (2011). An integrated conceptual framework for long-term social-ecological research. Frontiers in Ecology and the Environment, 9(6), 351-357.

Cruz Conejo, L. D., Chacón Ureña, E., \& Chacón Zúñiga, R. A. (2012). San Gerardo de Dota: en las montañas del Alto Savegre. San José, Costa Rica: Diseño Editorial MyF.

Delgado-Serrano, M. del M., \& Ramos, P. A. (2015). Making Ostrom's framework applicable to characterise social ecological systems at the local level. International Journal of the Commons, 9(2).

Duraiappah, A. K., Asah, S. T., Brondizio, E. S., Kosoy, N., O’Farrell, P. J., Prieur-Richard, A. H., ... Takeuchi, K. (2014). Managing the mismatches to provide ecosystem services for human well-being: A conceptual framework for understanding the new commons. Current Opinion in Environmental Sustainability, 7, 94-100.

Estrada, A., \& Zamora, N. (2004). Riqueza, cambios y patrones florísticos en un gradiente altitudinal en la cuenca hidrográfica del río Savegre, Costa Rica. Brenesia, (61), 1-52.

Folke, C., Pritchard Jr, L., Berkes, F., Colding, J., \& Svedin, U. (2007). The problem of fit between ecosystems and institutions: ten years later. Ecology and society, 12(1).

Frey, U., \& Rusch, H. (2013). Using artificial neural networks for the analysis of social-ecological systems. Ecology and Society, 18(2).

Gago García, C. (2000). Desarrollo sostenible en el medio tropical latinoamericano (el proyecto de desarrollo en la cuenca del río Savegre, Costa Rica). Anales de Geografía de la Universidad Complutense, 20, 253-264.

Galaz, V., Olsson, P., Hahn, T., Folke, C., \& Svedin, U. (2008). The problem of fit among biophysical systems, environmental and resource regimes, and broader governance systems: insights and emerging challenges. En O. R. Young, L. A. King, \& H. Schroeder (Eds.), Institutions and environmental change: principal findings, applications, and research frontiers (pp. 147-186). Cambridge, Mass: MIT Press. 
Gobierno de Costa Rica. (2015, agosto 29). Gobierno decretó salvaguarda ambiental de 25 años para ríos Pacuare y Savegre. Recuperado el 2 de julio de 2017, a partir de http://presidencia.go.cr/comunicados/2015/08/gobierno-decreto-salvaguarda-ambiental-de-25-anospara-rios-pacuare-y-savegre-2/

Harvey, C. A., \& Haber, W. A. (1998). Remnant trees and the conservation of biodiversity in Costa Rican pastures. Agroforestry systems, 44(1), 37-68.

Hinkel, J., Bots, P. W., \& Schlüter, M. (2014). Enhancing the Ostrom social-ecological system framework through formalization. Ecology and Society, 19(3), 51.

Hinkel, J., Cox, M. E., Schluter, M., Binder, C. R., \& Falk, T. (2015). A diagnostic procedure for applying the social-ecological systems framework in diverse cases. Ecology and Society, 20(1).

Ives, C. D., \& Kendal, D. (2014). The role of social values in the management of ecological systems. Journal of Environmental Management, 144, 67-72.

Jones, N., Shaw, S., Ross, H., Witt, K., \& Pinner, B. (2016). The study of human values in understanding and managing social-ecological systems. Ecology and Society, 21(1).

Leslie, H. M., Basurto, X., Nenadovic, M., Sievanen, L., Cavanaugh, K. C., Cota-Nieto, J. J., ... others. (2015). Operationalizing the socialecological systems framework to assess sustainability. Proceedings of the National Academy of Sciences, 112(19), 5979-5984.

Liu, J., Dietz, T., Carpenter, S. R., Alberti, M., Folke, C., Moran, E., ... Taylor, W. W. (2007). Complexity of coupled human and natural systems. Science, (5844), 1513.

Liu, J., Hull, V., Batistella, M., DeFries, R., Dietz, T., Fu, F., ... others. (2013). Framing sustainability in a telecoupled world. Ecology and Society, 18(2).

Liu, J., Mooney, H., Hull, V., Davis, S. J., Gaskell, J., Hertel, T., ... others. (2015). Systems integration for global sustainability. Science, 347(6225), 1258832.

McGinnis, M., \& Ostrom, E. (2014). Social-ecological system framework: initial changes and continuing challenges. Ecology and Society, 19(2).

MINAE, M. de A. y E. (2004). Plan de Manejo Integrado de la Cuenca Hidrográfica del Río Savegre. San José, Costa Rica: Programa Araucaria. 
Edgar Espinoza-Cisneros. Optimizing social-ecological analysis of coupled human-river systems through the integration of conceptual frameworks: the case of the Savegre watershed, Costa Rica

MINAE-AECI. (2001). Estudio socio-económico en 23 comunidades de la cuenca hidrográfica del río Savegre. San José, Costa Rica: Ministerio de Ambiente y Energía y la Agencia Española de Cooperación Internacional.

Molle, F. (2009). River-basin planning and management: The social life of a concept. Geoforum, 40, 484-494.

Nagendra, H., \& Ostrom, E. (2014). Applying the social-ecological system framework to the diagnosis of urban lake commons in Bangalore, India. Ecology and Society, 19(2), 1-18.

Ostrom, E. (2007). A diagnostic approach for going beyond panaceas. Proceedings of the national Academy of sciences, 104(39), 15181-15187.

Ostrom, E. (2009). A General Framework for Analyzing Sustainability of Social-Ecological Systems. Science, (5939), 419.

Partelow, S., \& Winkler, K. (2016). Interlinking ecosystem services and Ostrom's framework through orientation in sustainability research. Ecology and Society, 21(3).

Programa Estado de la Nación. (2016). Capítulo 4. Armonía con la Naturaleza. En Vegésimo Segundo Informe Estado de la Nación. San José, Costa Rica: Programa Estado de La Nación.

Sánchez, J. E., Barrantes, G., \& Duran, F. (2004). Distribución, ecología y conservación de la avifauna de la cuenca del río Savegre, Costa Rica. Brenesia, (61), 63-93.

Sanchez-Azofeifa, G. A. (2000). Land use and cover change in Costa Rica: a geographic perspective. En H. Charles, P. Van Laake, C. León, \& G. Leclerc (Eds.), Quantifying Sustainable Development: The Future of Tropical Economies (pp. 473-501). San Diego, CA: Academic Press.

Sánchez-Azofeifa, G. A., Daily, G. C., Pfaff, A. S., \& Busch, C. (2003). Integrity and isolation of Costa Rica's national parks and biological reserves: examining the dynamics of land-cover change. Biological Conservation, 109(1), 123-135.

Schlüter, M., Hinkel, J., Bots, P. W., \& Arlinghaus, R. (2014). Application of the SES framework for model-based analysis of the dynamics of social-ecological systems. Ecology and Society, 19(1), 36.

SINAC. (2017). Sistematización Desarrollo Sostenible de la Cuenca Hidrográfica del Río Savegre. Puntarenas, Costa Rica: Sistema Nacional De Áreas de Conservación - Ministerio de Ambiente y Energía. 
Edgar Espinoza-Cisneros. Optimizando el análisis socio-ecológico de sistemas acoplados humano-fluviales a través de la integración de marcos conceptuales: el caso de la cuenca del Savegre, Costa Rica

Torres Guevara, L. E. T., Schlüter, A., \& Lopez, M. C. (2016). Collective action in a tropical estuarine lagoon: adapting Ostrom's SES framework to Ciénaga Grande de Santa Marta, Colombia. International Journal of the Commons, 10(1).

USDA (United States Department of Agriculture). (2017). Coffee: World Markets and Trade. United States Department of Agriculture - Foreign Agricultural Service. Recuperado a partir de https://apps.fas. usda.gov/psdonline/circulars/coffee.pdf

Vörösmarty, C. J., McIntyre, P. B., Gessner, M. O., Dudgeon, D., Prusevich, A., Green, P., ... others. (2010). Global threats to human water security and river biodiversity. Nature, 467(7315), 555-561.

Young, O. R., Berkhout, F., Gallopin, G. C., Janssen, M. A., Ostrom, E., \& Van der Leeuw, S. (2006). The globalization of socio-ecological systems: an agenda for scientific research. Global Environmental Change, 16(3), 304-316.

Young, O. R., King, L. A., \& Schroeder, H. (Eds.). (2008). Institutions and environmental change: principal findings, applications, and research frontiers. Cambridge, Mass: MIT Press. 